\title{
Crab Shell Extract Improves Serum Biochemical Markers and Histological Changes of Pancreas in Diabetic Rats
}

\author{
El Extracto de Cáscara de Cangrejo Mejora los Marcadores Bioquímicos \\ del Suero y los Cambios Histológicos del Páncreas en Ratas Diabéticas
}

Fatemeh Makalani' ${ }^{1}$ Mohammad Rasool Khazaei ${ }^{1}$; Elham Ghanbari ${ }^{1}$ \& Mozafar Khazaei $^{1}$

MAKALANI, F.; KHAZAEI, M. R.; GHANBARI, E. \& KHAZAEI, M. Crab shell extract improves serum biochemical markers and histological changes of pancreas in diabetic rats. Int. J. Morphol., 35(4):1437-1443, 2017.

SUMMARY: Diabetes mellitus is a common metabolic disease. There are many natural agents available to control and treat diabetes. Crab shell extract has antioxidant properties. The aim of present study was to investigate the effect of crab shell hydroalcoholic extract on blood glucose, liver enzymes, nitric oxide and antioxidant capacity of serum and histological structure of pancreas in diabetic rats. In this experimental study, thirty five male Wistar rats (180-220 g) were divided into control, diabetic and experimental groups $(\mathrm{n}=7)$. Diabetes was induced by intraperitoneal injection of streptozotocin $(60 \mathrm{mg} / \mathrm{kg})$. Rats were treated for 14 days by crab shell extract with 100, 200 and $400 \mathrm{mg} / \mathrm{kg}$ doses. Fasting blood glucose, serum levels of liver enzymes, nitric oxide (NO) and total antioxidant capacity were evaluated. Changes of pancreatic tissue were determined using a modified aldehyde fuchsin staining method. Data were analyzed using one-way ANOVA. Differences were considered statistically significant at $\mathrm{P}<0.05$. Crab shell extract induced a significant reduction in blood glucose, serum levels of nitric oxide and ALT $(\mathrm{P}=0.033)$. Also, there were a significant increase in total antioxidant capacity (FRAP) $(\mathrm{P}=0.007)$, and insignificant decrease in serum levels of AST. The extract improved pancreatic tissue changes caused by diabetes. In conclusion, antioxidant and anti-diabetic effects of crab shell increase total antioxidant capacity of serum and decreased blood glucose, serum nitric oxide and ALT levels.

KEY WORDS: Diabetes mellitus; Crab shell; Antioxidant; Pancreas.

\section{INTRODUCTION}

Diabetes mellitus is a common metabolic disorder and is characterized by chronic increase in blood glucose due to absolute or relative deficiency of insulin secretion or through insulin resistance. Epidemiologic studies have confirmed the increase in the worldwide prevalence of diabetes mellitus (Holt, 2004). Based on the World Health Organization report, the number of diabetic patients in the world will rise from 171 million in 2000 to more than 300 million in 2025 (Wild et al., 2004). Long hyperglycemic periods, through glucose oxidation and protein glycosylation, can lead to production of free radicals, especially reactive oxygen species (ROS). These conditions disrupts the balance between ROS production and antioxidant defense mechanism in all tissues and results in cell dysfunction and changes in cell function, especially in pancreas (Robertson et al., 2003).

Liver has a main role in glucose homeostasis and its damage in diabetes mellitus includes fluctuating serum transaminases (ALT and AST), alkaline phosphatase (ALP) and result in the leakage of these hepatocyte enzymes into the bloodstream (Ramesh \& Pugalendi, 2006). Nitric oxide (NO) is significantly involved in pancreatic destruction, Oxidative stress and NO pathway are related and seem to modulate each other, leading to B-cell destruction after STZ administration (González et al., 2000).

Crustacean's shells such as crab contain natural ingredients, and its principal components are chitin (20-30 $\%)$, protein $(30-40 \%)$, calcium carbonate salts $(30-50 \%)$ and antioxidant compounds such as selenium and carotenoids (astaxanthin, astatine, and can-thaxanthin) (Cho et al., 1998). Chitin is the main component of crustacean shells and the most abundant biopolymer in the crab shell, shrimp, and insect's cuticle. Chitosan is a derivative of chitin which is obtained from chitin deacetylation (Ngo et al., 2008; Azuma et al., 2014). Its antitumor effects have been demonstrated in vitro and in vivo (Jeon \& Kim, 2002). Chitin and its derivatives like chitosan and chitooligosaccharides showed

${ }^{1}$ Fertility and Infertility Research Center, Kermanshah University of Medical Sciences, Kermanshah, Iran. 
anti-cancer, anti-microbial and hypoallergenic, antioxidant (Lin \& Chou, 2004), anti-inflammatory, cholesterol-lowering and coagulant properties (Kumar et al., 2004).

Crab shell has been introduced as one of the traditional remedies for the treatment and prevention of cancer, and its extract has effective inhibitory effects on breast cancer cell line (MCF7) (Rezakhani et al., 2014) and prostate cancer cell line (LNCap) (Rezakhani et al., 2017). It also exerts anti-proliferating effect on human umbilical vein endothelial cells (HUVECs) and reducing their nitric oxide production (Mirzapur et al., 2015).

Selenium is an essential part of the human diet and is found in crab shell. It inhibits tumor cell progress and it has protective effects against cancer (Brozmanová et al., 2010). Also, selenium has antioxidant and anti-inflammatory effects and can be effective in diabetes owing to its role in oxidative stress. Studies on diabetes in mice have shown that selenium protects mitochondria from oxidative stress (Akhuemokhan et al., 2013) and plays an important role in the metabolism of vitamin E. It is essential for the normal function of pancreas (Tabar, 2012),

Current drugs used for the treatment of diabetes are associated with several side effects such as hypoglycemia, weight gain, gastrointestinal disorders, peripheral edema and impaired liver function (Mallare et al., 2005), hence, there is a need for effective, safe and better oral hypoglycemic agents. According to antioxidant properties of compounds derived from crab shell, the present study was carried out to determine the effects of crab shell hydroalcoholic extract on blood glucose, liver enzymes, NO, antioxidant capacity of serum and histological structure of pancreas in diabetic rats.

\section{MATERIAL AND METHOD}

In this experimental study, thirty five male Wistar rats (180-220 g) were used. The rats were kept in standard conditions: at a temperature of $22 \pm 2{ }^{\circ} \mathrm{C}$ and $12 / 12 \mathrm{~h}$ lightdark cycle, with free access to food and water. All experimental procedures and care of animals were conducted based on the ethical principles for laboratory animals, approved by Kermanshah University of Medical Sciences. The rats were randomly divided into 5 groups ( $\mathrm{n}=7 /$ group): control (C) and Diabetic groups (D), and experimental groups: diabetic rats receiving hydroalcoholic extract of crab shell (D/100, D/200 and D/400 mg/kg).

Diabetes was induced by intraperitoneal injection of freshly prepared STZ (Sigma chemical company, St. Louis,
USA) at a dose of $60 \mathrm{mg} / \mathrm{kg} / \mathrm{BW}$ dissolved in $0.1 \mathrm{~mol} / \mathrm{L}$ citrate buffer (Ghanbari et al., 2016b). The animals were considered diabetic, if their blood glucose was above $250 \mathrm{mg} / \mathrm{dl} 3-5$ days after the STZ injection. The study periods were 14 days.

At the end of study, the rats in all groups were anesthetized with chloroform and were dissected. Blood samples were obtained by cardiac puncture, were centrifuged at $2500 \mathrm{~g}$ for 15 minute and their serum were separated. AST, ALT, and ALP of serum were determined by a diagnostic kit (Bio System, Spain). The serum was stored at $-20{ }^{\circ} \mathrm{C}$ to measure ferric reducing antioxidant power (FRAP) and NO assays. Pancreas was removed and fixed in $10 \%$ buffer formalin, and histological slides were prepared and stained with $\mathrm{H} \& \mathrm{E}$ and modified aldehyde fuchsine method (Noorafshan et al., 2012).

In this study, a crab shell (Potamon persicum) whose genus and species were confirmed and identified by a systematic zoologist (Razi University, Kermanshah, Iran) was used. Crab shells were dried and ground by an electrical mill and $20 \mathrm{~g}$ of powder was dissolved in $400 \mathrm{ml}$ of $70 \%$ ethanol for 48 hours in darkness. It was subsequently filtered through filter paper and dried to evaporate the alcohol; the final powder was stored in $4^{\circ} \mathrm{C}$. To determine the LD50 of extract, it was administered to two groups (5 mice each) at doses of 1000 and $2000 \mathrm{mg} / \mathrm{kg}$ of body weight interaperitonealy. The mice were evaluated until 48 hours for symptoms of toxicity and mortality. Mortality was not observed in two groups of mice (Farzaei et al., 2013).

FRAP assay is intended to measure the ability of plasma in reducing the capacity of $\mathrm{Fe}^{3+}$ to $\mathrm{Fe}^{2+}$ in the presence of TPTZ (2, 4, 6 tripyridyl, 1, 3, 5 triazine). Blue-colored complex was formed by ferrous reaction with TPTZ. Standard solutions of $\mathrm{FeSo}_{4} \cdot 7 \mathrm{H}_{2} \mathrm{O}$ were prepared with concentrations of 125,250 , $500,1000 \mathrm{mM}$, and $1.5 \mathrm{ml} \mathrm{FRAP} \mathrm{reagent} \mathrm{was} \mathrm{added} \mathrm{to} 150 \mu \mathrm{l}$ of distilled water and $50 \mu \mathrm{l}$ of serum to the above solution. Reaction was started and placed in a water bath equipped with a shaker for 10 minutes. The absorption was measured at 593 $\mathrm{nm}$ using a spectrophotometer (Jenway 36200, England) (Ghanbari et al., 2016a).

Nitric oxide is a free radical with a very short half-life in biological systems. NO production takes place through activity of NO synthase enzyme. NO is converted into nitrite and nitrate after oxidation. NO measurement was performed indirectly by measuring its stable metabolites, nitrate and nitrite. NO was measured using the Griess method. Zinc powder was used to plasma deproteinization, and the samples were centrifuged (10000 g, $10 \mathrm{~min}$ ). Vanadium chloride was used for nitrate reduction to nitrite. Standard solutions of sodium nitrate were prepared with different concentrations and 
the standard curve of nitrite concentration was calculated by micromoles per liter. Based on nitrate concentration, a range of purple color with different intensities was created. Light absorbance was assayed using an ELISA Reader at wavelengths of $540 \mathrm{~nm}$ (Khazaei et al., 2011).

The results were presented as mean $\pm \mathrm{SE}$ and data were analyzed by One-way ANOVA and Tukey test using SPSS software (version 16). $\mathrm{P}<0.05$ was considered significant.

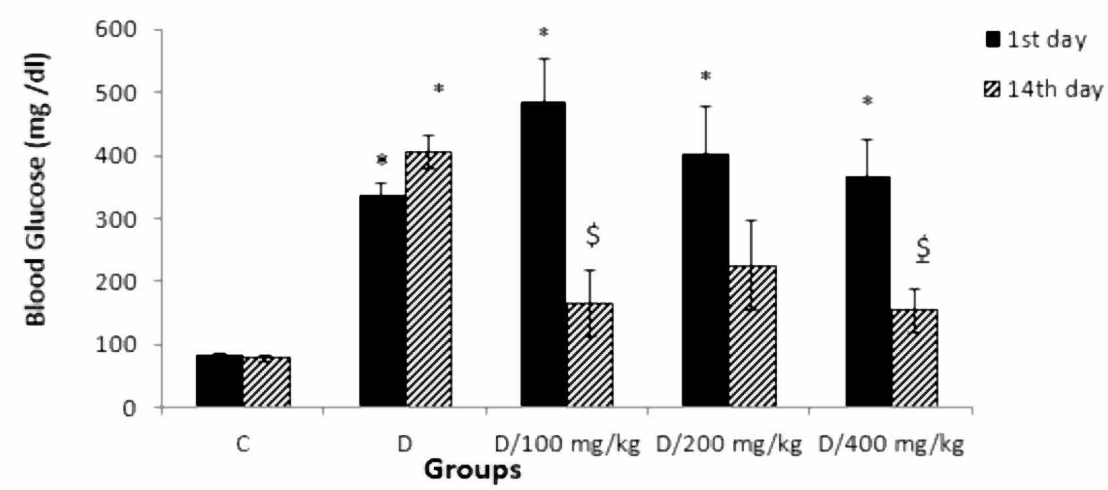

Fig. 1: Fasting serum levels of glucose in control, diabetic and experimental groups at the first and 14th days of the study. C: control, D: diabetic and diabetic groups treated with exact $(\mathrm{D} / 100, \mathrm{D} / 200$ and $\mathrm{D} / 400 \mathrm{mg} / \mathrm{kg}$ ). \$: significant differences with diabetic group and *: significance differences compared to control group at $\mathrm{p}<0.05$.

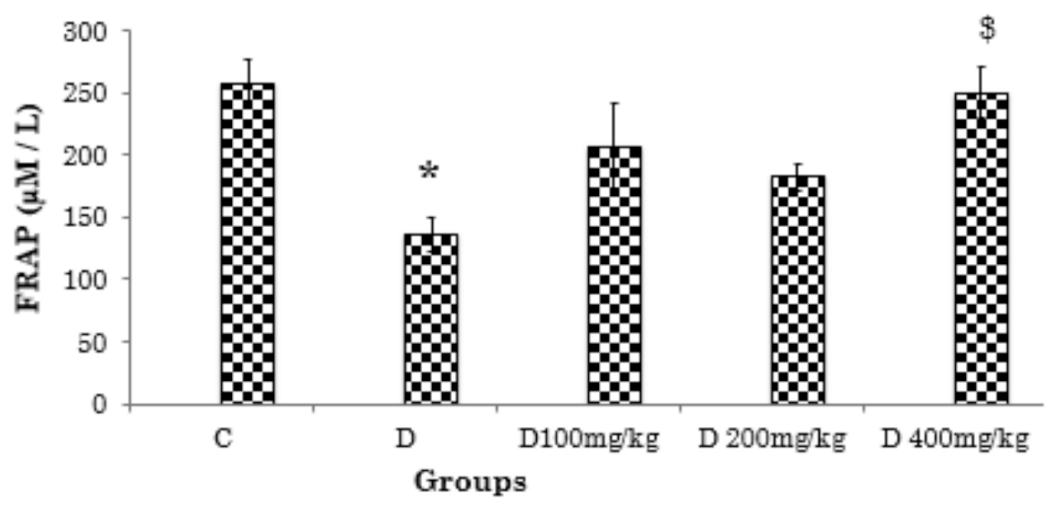

Fig. 2. Effect of crab shell extract on FRAP level of serum in control and experimental groups. $* \mathrm{P}<0.05$ compared to control group. \$: $\mathrm{P}<0.05$ compared to Diabetic group.

Table I Means of body weight $(\mathrm{g})$ in control, diabetic and diabetic groups treated with crab shell extract.

\begin{tabular}{lccc}
\hline Groups N=7 & Primary weight $(\mathrm{g})$ & weight after injec tion STZ & Final weight $(\mathrm{g})$ \\
\hline $\mathrm{C}$ & $228 \pm 7.14$ & $212 \pm 8.92$ & $205 \pm 8.16$ \\
$\mathrm{D}$ & $178 \pm 9.09^{*}$ & $193 \pm 10$ & $211 \pm 9.41$ \\
$\mathrm{D} / 100 \mathrm{mg} / \mathrm{kg}$ & $183 \pm 9.88^{*}$ & $186 \pm 3.83$ & $199 \pm 5.09$ \\
$\mathrm{D} / 200 \mathrm{mg} / \mathrm{kg}$ & $199 \pm 1.76$ & $179 \pm 3.11$ & $208 \pm 5.77$ \\
$\mathrm{D} / 400 \mathrm{mg} / \mathrm{kg}$ & $189 \pm 11.75^{*}$ & $197 \pm 12.61$ & $222 \pm 7.76$ \\
\hline
\end{tabular}

Data are expressed as mean \pm SE. *: $\mathrm{p}<0.05$ compared to control group C: control, D: diabetic, D/100 $\mathrm{mg} / \mathrm{kg}, \mathrm{D} / 200 \mathrm{mg} / \mathrm{kg}$ and $\mathrm{D} / 400 \mathrm{mg} / \mathrm{kg}$ : diabetic groups treated with extract.

\section{RESULTS}

The means of blood glucose level were $79 \pm 4.98,404$ $\pm 26.43,165 \pm 51.27,187 \pm 38.50$ and $153 \pm 33.50$ for control, diabetic, and 100, 200 and $400 \mathrm{mg} / \mathrm{kg}$ doses of crab sell extract respectively. They showed significant difference $(\mathrm{p}=0.000)$ (Fig. 1), blood glucose was reduced in all experimental groups and 100 and $400 \mathrm{mg} / \mathrm{kg}$ doses showed significant difference compare to diabetic groups. Extract groups did not have significant difference with control group.

Diabetes decreased body weight significantly and there was a significant difference between groups at the end of study $(\mathrm{p}=0.003)$ (Table I). Diabetes led to a significant decrease in the serum reduction capacity $(\mathrm{p}=0.009)$. FRAP amounts were reported $250 \pm 19.2$, $135 \pm 14,206 \pm 34.7,182 \pm 10.9$, and $250 \pm 20.1$ in control, diabetic, 100 , 200 and $400 \mathrm{mg} / \mathrm{kg}$ doses of extract respectively. FRAP level was increased in all extract groups and the $400 \mathrm{mg} / \mathrm{kg}$ dose of extract showed a significant difference compared to diabetic group $(\mathrm{p}=0.014)$ (Fig. 2).

Serum level of NO increased significantly in diabetic group, and different doses of extract decreased NO levels significantly $(\mathrm{P}=0.001)$ (Fig. 3). NO levels reached to control level in $100 \mathrm{mg} / \mathrm{kg}$ dose of extract. Serum level of AST decreased in extract groups insignificantly $(\mathrm{p}=0.27)$ compared to diabetic group, (Fig. 4). The ALP level was different between groups and it was elevated significantly in diabetic $(\mathrm{p}=0.029)$ and $400 \mathrm{mg} / \mathrm{kg}$ groups $(\mathrm{p}=0.007)$ compare to control (Fig. 5). The elevated level of ALT in diabetic rats was decreased by crab shell extract significantly $(p=0.019)$. All doses of extract decreased ALT level, but $400 \mathrm{mg} /$ $\mathrm{kg}$ showed significant differences compared to diabetic group (Fig. 6). 


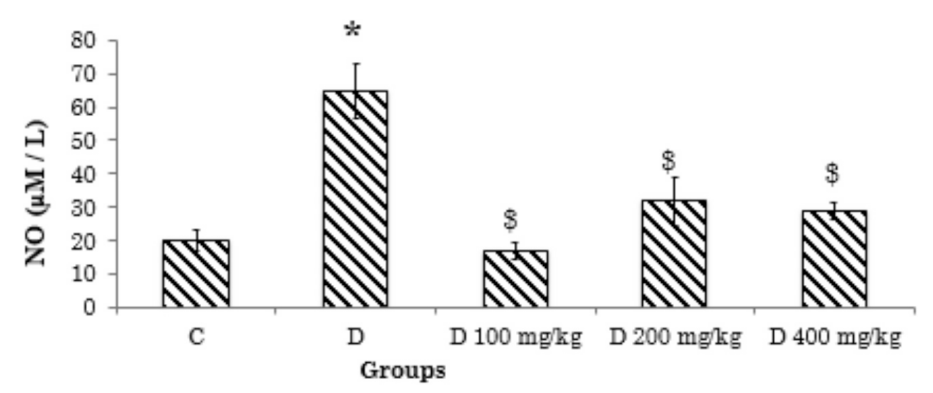

Fig. 3. Serum Levels of NO in control (C), diabetic (D), diabetic groups receiving crab shell extract 100, 200 and $400 \mathrm{mg} / \mathrm{kg}$, *: significant differences compared to control group and \$: compared to diabetic group $(\mathrm{p}<0.05)$.

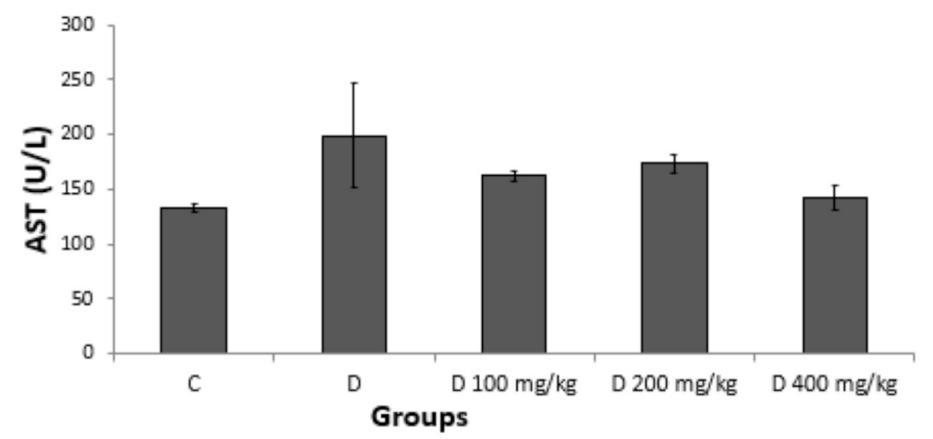

Fig. 4. Mean of AST levels in control and experimental groups; AST levels of in 100, 200 and $400 \mathrm{mg} / \mathrm{kg}$ doses of extract showed no significant difference with control group.

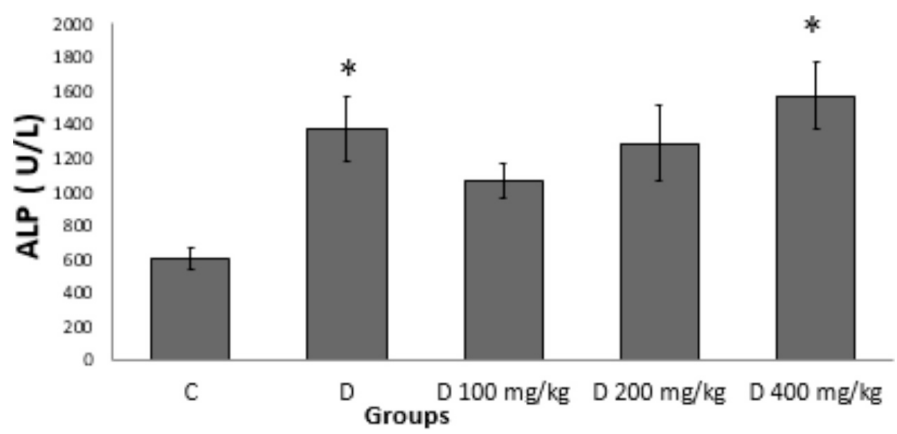

Fig. 5. Effect of crab shell extract on ALP level of serum in control and experimental groups. $* \mathrm{p}<0.05$ compared to control (C) group.

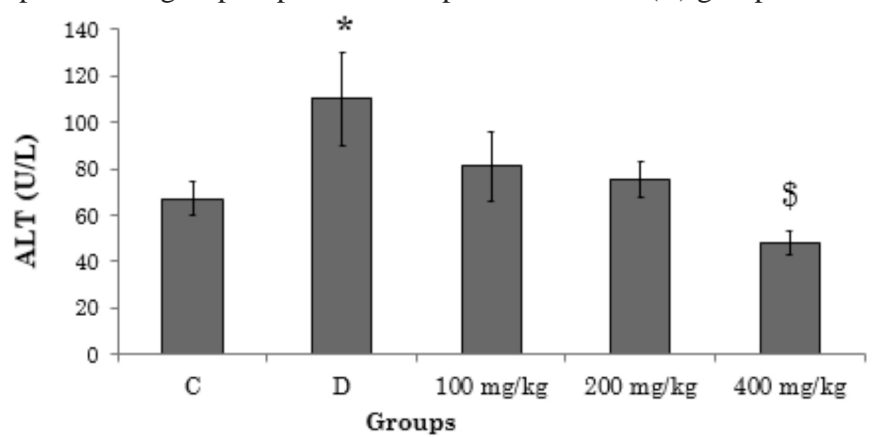

Fig. 6. Serum Levels of ALT in control (C), diabetic (D), diabetic animals receiving crab shell extract at doses 100, 200 and $400 \mathrm{mg} / \mathrm{kg}(\mathrm{D} / 100$, $200,400 \mathrm{mg} / \mathrm{kg}$ ). *: compared to control group and \$L: $\mathrm{p}<0.05$ compared to diabetic group indicate significant differences.
Modified aldehyde fuchsin staining showed that pancreas of the diabetic rats had irregular islet with decreased secretory granules in beta cells, but changes of pancreatic islet in the animals were minimized by administration of extract. Treatment with extract revealed few vacuoles in $\beta$ cells and increased secretory granules compared to the diabetic ones (Fig. 7).

\section{DISCUSSION}

In the current study, the antidiabetic effects of hydroalcoholic extract of crab shell on blood biochemical markers and histological structure of pancreas in diabetic rats were examined. To our knowledge, the present study is the first report regarding the effectiveness of crab shell on the serum biomarkers and antioxidant status in diabetic rats. Crab shell extract decreased levels of blood glucose, NO, ALT and AST in serum. Total antioxidant capacity was also increased significantly.

Different doses of extract improved pancreatic tissue damages caused by diabetes. In this study, diabetes decreased FRAP levels of serum and $400 \mathrm{mg}$ / $\mathrm{kg}$ of extract had the highest antioxidant activity among the treated groups, which might be due to active antioxidant components of crab shell such as carotenoids and selenium. A study reported that FRAP level in diabetic rats decreased significantly (Cakatay \& Kayali, 2006). Another study demonstrated that aminoethyl-chitooligosaccharides have antioxidant activity through reduction of free radicals (Ngo et al., 2012). Also antioxidant properties of chitosan obtained from crab shell have been examined in previous investigations (Yen et al., 2008).

Crab shell contains selenium and betacarotene with protective or inhibitory effects on oxidative stress (Rezakhani et al., 2014; Rezakhani et al., 2017). Selenium is a component of enzymecatalyzed that redox reaction and acts as an antioxidant in the form of selenoproteins (Sheng et al., 2005), thus, it is concluded that the extract can elevate antioxidant activity or decrease oxidative stress in the blood of diabetic rats. The results of present study revealed that serum levels of nitric oxide of diabetic rats showed a significant increase in comparison to other groups and all doses of extract reduced serum levels of NO, and it was near to control in $100 \mathrm{mg} / \mathrm{kg}$ dose of crab shell extract. 

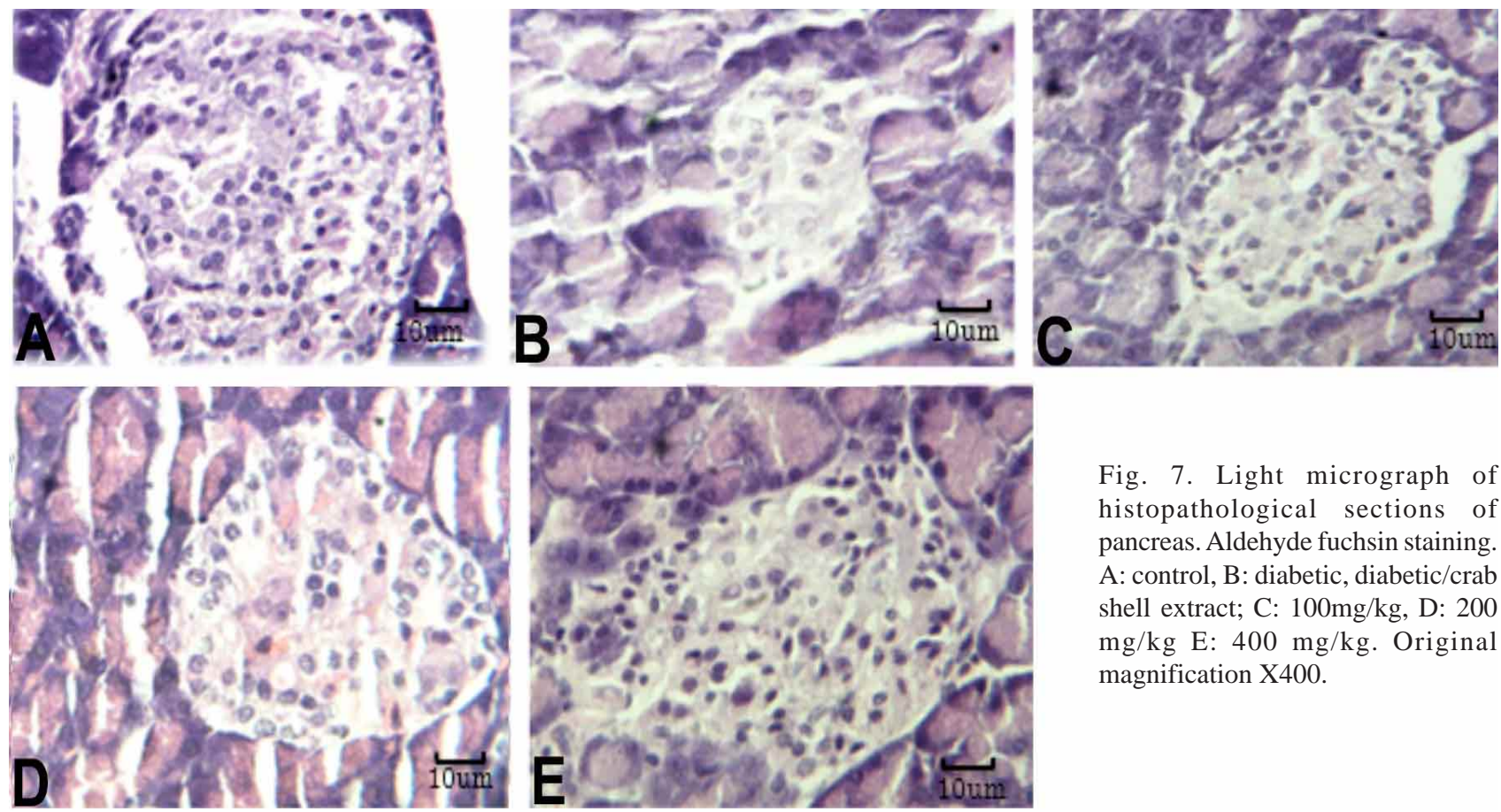

Fig. 7. Light micrograph of histopathological sections of pancreas. Aldehyde fuchsin staining. A: control, B: diabetic, diabetic/crab shell extract; C: $100 \mathrm{mg} / \mathrm{kg}$, D: 200 $\mathrm{mg} / \mathrm{kg} \mathrm{E}: 400 \mathrm{mg} / \mathrm{kg}$. Original magnification $\mathrm{X} 400$.

Cytokines like interleukin-1 inhibit insulin secretion through destruction in pancreatic $\beta$ cells. Elevated levels of interleukin- 1 and other cytokines activate the expression of NO synthesis, which produces high levels of NO free radicals (Mandrup-Poulsen et al., 1985). Studies have shown chitosan oligosaccharide exerts anti-inflammatory effects by inhibiting the formation of NO in macrophages (Yang et al., 2010). One of the possible mechanisms of damage to $b$ cells in the STZ induction diabetes may be NO overproduction, which is followed by oxidative stress. This overproduction of NO in STZ-induced diabetes is likely to be an important part of a complex autoimmune reaction that causes the destruction of pancreatic $\beta$ cells (Corbett et al., 1993).

Studies have shown that diabetes increases the serum levels of liver enzymes (Abolfathi et al., 2012), which is consistent with the findings of the present study. Liver is one of the main targets of insulin and plays an important role in the maintenance and stability of blood glucose (Parker et al., 2004). On other hand, since insulin suppresses gluconeogenic genes and ALT is a gluconeogenic enzyme, in the course of diabetes, insulin signaling is impaired and ALT production is increased (Vozarova et al., 2002).

The results of this study showed that diabetes elevate AST and ALT biomarkers compared with the control group, and treatment with different doses of crab shell extract improved the above mentioned changes, while crab shell extract increased ALP in a dose-dependent manner. A study showed that chitooligosaccharide has long-term anti-diabetic effects on STZ-induced diabetes in rats by improving glucose metabolism and increasing the secretory capacity of pancreas cells (Kim et al., 2009), which is consistent with the histological findings of pancreatic tissue in present study. Few researches have examined the impact of chitosan on liver biomarkers. Since the present study is the first study to analyze the effect of crab shell extract on diabetes, further research is needed to be conducted in this regard.

\section{CONCLUSION}

Crab shell extract showed significant anti-diabetic and antioxidant activity. This antioxidant activity could improve biochemical changes caused by diabetes. Indeed, it exerted healing effects on pancreatic tissue.

\section{ACKNOWLEDGEMENTS}

This article originated from M.Sc thesis supported by Kermanshah University of Medical Sciences, Iran. The authors wish to express gratitude to Fertility and Infertility Research Center, Kermanshah University of Medical Sciences. 
MAKALANI, F.; KHAZAEI, M. R.; GHANBARI, E. \& KHAZAEI, M. El extracto de cáscara de cangrejo mejora los marcadores bioquímicos del suero y los cambios histológicos del páncreas en ratas diabéticas. Int. J. Morphol., 35(4):14371443, 2017.

RESUMEN: La diabetes mellitus es una enfermedad metabólica común. Hay muchos agentes naturales disponibles para controlar y tratar la diabetes. El extracto de cáscara de cangrejo tiene propiedades antioxidantes. El objetivo del presente estudio fue investigar el efecto del extracto hidroalcohólico de la cáscara de cangrejo sobre la glucosa sérica, las enzimas hepáticas, el óxido nítrico y la capacidad antioxidante del suero y la estructura histológica del páncreas en ratas diabéticas. En este estudio experimental, treinta y cinco ratas Wistar machos (180220 g) se dividieron en cinco grupos: control, diabéticos y experimentales $(n=7)$. La diabetes se indujo por inyección intraperitoneal de estreptozotocina $(60 \mathrm{mg} / \mathrm{kg})$. Las ratas se trataron durante 14 días con extracto de cáscara de cangrejo con dosis de 100, 200 y $400 \mathrm{mg} / \mathrm{kg}$. Se evaluaron la glucosa en sangre en ayunas, las enzimas hepáticas, el óxido nítrico sérico y la capacidad antioxidante total. Los cambios en el tejido pancreático se determinaron usando un método de tinción de aldehído fucsina modificado. Los datos se analizaron utilizando ANOVA unidireccional. Las diferencias se consideraron estadísticamente significativas a $\mathrm{P}<0,05$. El extracto de cáscara de cangrejo indujo una reducción significativa en la glucosa en sangre, en los niveles séricos de óxido nítrico y ALT $(\mathrm{P}=0,033)$. Además se observó un aumento significativo en la capacidad antioxidante total (FRAP) $(\mathrm{P}=0.007)$, y una disminución insignificante en los niveles séricos de AST. El extracto mejoró los cambios en el tejido pancreático causados por la diabetes. En conclusión, los efectos antioxidantes y antidiabéticos de la cáscara de cangrejo aumentan la capacidad antioxidante total de suero y la disminución de la glucosa en la sangre, el óxido nítrico sérico y los niveles de ALT.

PALABRAS CLAVE: Diabetes mellitus; Cangrejo; Antioxidante; Páncreas.

\section{REFERENCES}

Abolfathi, A. A.; Mohajeri, D.; Rezaie, A. \& Nazeri, M. Protective effects of green tea extract against hepatic tissue injury in streptozotocininduced diabetic rats. Evid. Based Complement. Alternat. Med., 2012:740671, 2012.

Akhuemokhan, I. K.; Eregie, A. \& Fasanmade, O. A. Diabetes prevention and management: the role of trace minerals. Afr. J. Diabetes Med., 21(2):37-41, 2013 .

and inflammation in murine microglial BV-2 cells. Carbohydr. Polym., 88:743-7, 2012

Azuma, K.; Ifuku, S.; Osaki, T.; Okamoto, Y. \& Minami, S. Preparation and biomedical applications of chitin and chitosan nanofibers. $J$. Biomed. Nanotechnol., 10(10):2891-20, 2014.

Brozmanová, J.; Mániková, D.; Vlc ková, V. \& Chovanec, M. Selenium: a double-edged sword for defense and offence in cancer. Arch. Toxicol., 84(12):919-38, 2010.

Cakatay, U. \& Kayali, R. The evaluation of altered redox status in plasma and mitochondria of acute and chronic diabetic rats. Clin. Biochem., 39(9):907-12, 2006.

Cho, Y. I.; No, H. K. \& Meyers, S. P. Physicochemical characteristics and functional properties of various commercial chitin and chitosan products. J. Agric. Food Chem., 46(9):3839-43, 1998.

Corbett, J. A.; Wang, J. L.; Misko, T. P.; Zhao, W.; Hickey, W. F. \& Mcdaniel, M. L. Nitric oxide mediates IL-1b-induced islet dysfunction and destruction: Prevention by dexamethasone. Autoimmunity, 15(2):14553, 1993.

Farzaei, M. H.; Khazaei, M.; Abbasabadei, Z.; Feyzmahdavi, M. \& Mohseni, G. R. Protective effect of tragopogon graminifolius DC against ethanol induced gastric ulcer. Iran. Red Crescent Med. J., 15(9):813-6, 2013.

Ghanbari, E.; Nejati, V. \& Khazaei, M. Antioxidant and protective effects of Royal jelly on histopathological changes in testis of diabetic rats. Int. J. Reprod. Biomed. (Yazd), 14(8):519-26, 2016a.

Ghanbari, E.; Nejati, V. \& Khazaei, M. Improvement in serum biochemical alterations and oxidative stress of liver and pancreas following use of royal jelly in streptozotocin-induced diabetic rats. Cell J., 18(3):362$70,2016 b$.

González, E.; Roselló-Catafau, J.; Jawerbaum, A.; Sinner, D.; Pustovrh, C.; Vela, J.; White, V.; Xaus, C.; Peralta, C. \& Gimeno, M. Pancreatic nitric oxide and oxygen free radicals in the early stages of streptozotocininduced diabetes mellitus in the rat. Braz. J. Med. Biol. Res., 33(11):1335-42, 2000.

Holt, R. I. Diagnosis, epidemiology and pathogenesis of diabetes mellitus: an update for psychiatrists. Br. J. Psychiatry Suppl., 47:S55-63, 2004.

Jeon, Y. J. \& Kim, S. K. Antitumor activity of chitosan oligosaccharides produced in ultrafiltration membrane reactor system. J. Microbiol. Biotechnol., 12(3):503-7, 2002.

Khazaei, M.; Roshankhah, S.; Ghorbani, R. \& Chobsaz, F. Sildenafil effect on nitric oxide secretion by normal human endometrial epithelial cells cultured in vitro. Int. J. Fertil. Steril., 5(3):142-7, 2011.

Kim, J. N.; Chang, I. Y.; Kim, H. I. \& Yoon, S. P. Long-term effects of chitosan oligosaccharide in streptozotocin-induced diabetic rats. Islets, 1(2):111-6, 2009

Kumar, M. R.; Muzzarelli, R. A.; Muzzarelli, C.; Sashiwa, H. \& Domb, A. J. Chitosan chemistry and pharmaceutical perspectives. Chem. Rev., 104(12):6017-84, 2004.

Lin, H. Y. \& Chou, C. C. Antioxidative activities of water-soluble disaccharide chitosan derivatives. Food Res. Int., 37:883-9, 2004.

Mallare, J. T.; Karabell, A. H.; Velasquez-Mieyer, P.; Stender, S. R. \& Christensen, M. L. Current and future treatment of metabolic syndrome and type 2 diabetes in children and adolescents. Diabetes Spectr., 18(4):220-8, 2005.

Mandrup-Poulsen, T.; Bendtzen, K.; Nielsen, J. H.; Bendixen, G. \& Nerup, $\mathrm{J}$. Cytokines cause functional and structural damage to isolated islets of Langerhans. Allergy, 40(6):424-9, 1985.

Mirzapur, P.; Rashidi, Z.; Rezakhani, L. \& Khazaei, M. In vitro inhibitory effect of crab shell extract on human umbilical vein endothelial cell. In vitro Cell. Dev. Biol. Anim., 51(1):36-41, 2015.

Ngo, D. H.; Ngo, D. N.; Vo, T. S.; Ryu, B.; Van Ta, Q. \& Kim, S. K. Protective effects of aminoethyl-chitooligosaccharides against oxidative stress

Ngo, D. N.; Kim, M. M. \& Kim, S. K. Chitin oligosaccharides inhibit oxidative stress in live cells. Carbohydr. Polym., 74(2):228-34, 2008.

Noorafshan, A.; Hoseini, L.; Karbalay-Doust, S. \& Nadimi, E. A simple stereological method for estimating the number and the volume of the pancreatic beta cells. JOP, 13(4):427-32, 2012.

Parker, G.; Taylor, R.; Jones, D. \& McClain, D. Hyperglycemia and inhibition of glycogen synthase in streptozotocin-treated mice: role of O-linked N-acetylglucosamine. J. Biol. Chem., 279(20):20636-42, 2004.

Ramesh, B. \& Pugalendi, K. V. Impact of umbelliferone (7hydroxycoumarin) on hepatic marker enzymes in streptozotocin diabetic rats. Indian J. Pharmacol., 38(3):209-10, 2006.

Rezakhani, L.; Khazaei, M. R.; Ghanbari, A. \& Khazaei, M. Crab shell extract induces prostate cancer cell line (LNcap) apoptosis and decreases 
MAKALANI, F.; KHAZAEI, M. R.; GHANBARI, E. \& KHAZAEI, M. Crab shell extract improves serum biochemical markers and histological changes of pancreas in diabetic rats. Int. J. Morphol., 35(4):1437-1443, 2017.

nitric oxide secretion. Cell J., 19(2):231-7, 2017.

Rezakhani, L.; Rashidi, Z.; Mirzapur, P. \& Khazaei, M. Antiproliferatory Effects of Crab Shell Extract on Breast Cancer Cell Line (MCF7). J. Breast Cancer, 17(3):219-25, 2014.

Robertson, R. P.; Harmon, J.; Tran, P. O.; Tanaka, Y. \& Takahashi, H. Glucose toxicity in beta-cells: type 2 diabetes, good radicals gone bad, and the glutathione connection. Diabetes, 52(3):581-7, 2003.

Sheng, X. Q.; Huang, K. X. \& Xu, H. B. Influence of alloxan-induced diabetes and selenite treatment on blood glucose and glutathione levels in mice. J. Trace Elem. Med. Biol., 18(3):261-7, 2005.

Tabar, M. B. Determination of serum selenium in patients with type II diabetes mellitus. Middle East J. Sci. Res., 12:433-5, 2012.

Vozarova, B.; Stefan, N.; Lindsay, R. S.; Saremi, A.; Pratley, R. E.; Bogardus, C. \& Tataranni, P. A. High alanine aminotransferase is associated with decreased hepatic insulin sensitivity and predicts the development of type 2 diabetes. Diabetes, 51(6):1889-95, 2002.

Wild, S.; Roglic, G.; Green, A.; Sicree, R. \& King, H. Global prevalence of diabetes: estimates for the year 2000 and projections for 2030. Diabetes Care, 27(5):1047-53, 2004.

Yang, E. J.; Kim, J. G.; Kim, J. Y.; Kim, S. C.; Lee, N. H. \& Hyun, C. G. Anti-inflammatory effect of chitosan oligosaccharides in RAW 264.7 cells. Cent. Eur. J. Biol., 5(1):95-102, 2010.

Yen, M. T.; Yang, J. H. \& Mau, J. L. Antioxidant properties of chitosan from crab shells. Carbohydr. Polym., 74(4):840-4, 2008.

\section{Corresponding author: \\ Mozafar Khazaei}

Fertility and Infertility Research Center

Kermanshah University of Medical Sciences

Kermanshah

IRAN

Email: mkhazaei1345@yahoo.com

Received: 16-03-2017

Accepted: 28-08-2017 